\title{
Analisis Status Gizi dengan Prestasi Belajar Pada Siswa di SDN Mawar 8 Kota Banjarmasin
}

\author{
Nutritional Status Analysis With Learning Achievements In Students In Banjarmasin \\ Mawar 8 State Elementary School
}

\author{
Abdullah*, Norfai \\ Fakultas Kesehatan Masyarakat Universitas Islam Kalimantan (UNISKA) MAB Banjarmasin \\ Jl. Adhyaksa No. 2, Kayu Tangi, Kota Banjarmasin, Kalimantan Selatan \\ *korespondensi : abdullahmfks08@gmail.com
}

\begin{abstract}
Nutritional status is one of the factors that can affect learning achievement. School-age children who are malnourished will cause children to become weak, tired and sick, so children are often absent and have difficulty following and understanding the lesson. Nutritional conditions will also affect children's ability to understand lessons in school and influence learning achievement. This research is an analytical survey with a cross sectional approach. The population in this study was all students from grade 1 to grade 4 in Banjarmasin SDN Mawar 8 in 2018 totaling 83 students. The sample size was 69 respondents with cluster sampling technique. Nutritional status data were obtained using the Body Mass Index (BMI) by age (BMI/U), ie children aged 5-18 years by performing high measurements and using microtoice and weight measurements using digital scales and recording data types and age data in full years and months. Learning achievement data is obtained based on the value of the last report card. Data were analyzed using univariate and bivariate Che Square tests using computer programs with a confidence level of $95 \%$. Statistically there is a significant relationship between nutritional status and learning prestige in Banjarmasin SDN Mawar 8 with p-value (0.014) < $\alpha(0.05)$. Based on the results of the study, it was suggested the need for cooperation from the school with parents of students in terms of providing a healthy and nutritious breakfast and lunch, while also conducting further research studies on the most basic causes using a case control approach and multivariate testing for knowing the dominant causal factors for student achievement.
\end{abstract}

Keywords : Nutritional Status, Learning Achievement

\section{Pendahuluan}

Status gizi merupakan salah satu faktor yang dapat berpengaruh terhadap prestasi belajar di samping faktor lain, seperti faktor keluarga, lingkungan, motivasi, serta sarana, dan prasarana yang didapatkan di sekolah. Anak usia sekolah tidak termasuk ke dalam kelompok yang memiliki risiko kematian tinggi (1). Masalah gizi berupa gizi kurang dan gizi lebih perlu mendapat perhatian demi tercapainya tujuan pembangunan Sustainable Development Goals (SDGs). Sustainable Development Goals (SDGs) merupakan suatu rencana aksi global yang disepakati oleh para pemimpin dunia, termasuk Indonesia, guna mengakhiri kemiskinan, mengurangi kesenjangan dan melindungi lingkungan. SDGs berisi 17 Tujuan dan 169 Target yang diharapkan dapat dicapai pada tahun 2030, salah satu tujuannya adalah mengakhiri kelaparan, mencapai ketahanan pangan dan nutrisi yang lebih baik dan mendukung pertanian berkelanjutan.

Pemenuhan kebutuhan gizi pada anak menjadi masalah kesehatan di seluruh dunia. Sebagian besar gangguan perkembangan pada anak sangat terkait dengan status gizi anak itu sendiri yang diakibatkan oleh kesulitan makan. Hal ini dapat menyebabkan terjadinya malnutrisi, dehidrasi, berat badan kurang, ketidakseimbangan elektrolit, gangguan perkembangan kognitif, gangguan kecemasan, dan pada keadaan yang lebih parah dapat menjadi kondisi yang mengancam hidup (2).

Sumber daya manusia yang baik dan berkualitas sangat diperlukan dalam mengisi dan mempertahankan kemerdekaan. Kualitas sumber daya manusia merupakan salah satu faktor utama yang diperlukan dalam melaksanakan pembangunan nasional. Untuk meningkatkan kualitas 
sumber daya manusia tersebut maka harus dilakukan upaya-upaya yang saling berkesinambungan. Beberapa faktor yang mempengaruhi kualitas sumber daya manusia, faktor kesehatan dan gizi memegang peranan penting, karena orang tidak akan dapat mengembangkan kapasitasnya secara maksimal apabila yang bersangkutan tidak memiliki status kesehatan dan gizi yang optimal. Upaya peningkatan kualitas sumber daya manusia baik fisik maupun non fisik harus dilaksanakan sedini mungkin dan berlangsung terus menerus selama hidup. Salah satu upaya yang harus dilaksanakan adalah perbaikan, peningkatan gizi dan kesehatan. Upaya peningkatan gizi yang tepat dilakukan pada masa anak-anak. Kurang gizi akan menyebabkan kegagalan pertumbuhan fisik dan perkembangan kecerdasan, menurunkan daya tahan tubuh (3).

Pada anak usia sekolah kekurangan gizi akan mengakibatkan anak menjadi lemah, cepat lelah dan sakit-sakitan sehingga anak seringkali absen serta mengalami kesulitan mengikuti dan memahami pelajaran. Keadaan gizi juga akan mempengaruhi kemampuan anak dalam mengikuti pelajaran di sekolah dan akan mempengaruhi prestasi belajar, karena salah satu cara menilai kualitas seorang anak adalah dengan melihat prestasi belajarnya di sekolah. Proses belajar yang dilakukan seseorang merupakan suatu proses yang sangat komplek dipengaruhi oleh banyak faktor baik dari diri sendiri maupun dari luar diri manusia tersebut (3).

Menurut Cakrawati D. (2012) dalam Sa'adah (4) menyatakan bahwa fase usia sekolah membutuhkan asupan makanan yang bergizi untuk menunjang masa pertumbuhan dan perkembangannya, selain untuk kebutuhan energi, asupan makanan yang bergizi juga mempengaruhi perkembangan otak, apabila makanan tidak cukup mengandung zat-zat gizi yang dibutuhkan, dan keadaan ini berlangsung lama, akan menyebabkan perubahan metabolisme otak.

Keadaan status gizi dan indeks prestasi merupakan gambaran apa yang dikonsumsi anak Sekolah Dasar (SD) dalam jangka waktu yang lama, dapat berupa gizi kurang maupun gizi lebih. Zat-zat gizi seperti karbohidrat, protein, maupun zat gizi lainnya khususnya zat besi, dalam metabolisme tubuh berperan dalam proses berpikir atau proses penalaran serta daya konsentrasi dan sangat berkaitan erat dengan efisiensi belajar (4).

Indonesia menghadapi masalah gizi ganda, yaitu masalah gizi kurang dan masalah gizi lebih. Masalah gizi kurang pada umumnya disebabkan oleh kemiskinan, kurangnya persediaan pangan, kurang baiknya kualitas lingkungan, kurangnya pengetahuan masyarakat tentang gizi, menu seimbang dan kesehatan dan adanya daerah miskin gizi. Masalah gizi lebih disebabkan oleh kemajuan ekonomi pada lapisan masyarakat tertentu disertai dengan kurangnnya pengetahuan tentang gizi menu seimbang dan kesehatan (5).

Survei Gizi Asia Tenggara Kelompok studi (SEANUTS), di Indonesia, Malaysia, Thailand, dan Vietnam, melaporkan prevalensi gizi buruk 21,6\% dan 19,2\% anak-anak stunting. Dimana ringan, sedang malnutrisi ditemukan disebagian besar wilayah Indonesia, kekurangan gizi sedang adalah 25,2\%, dan anak-anak kerdil $29 \%$. Masalah kesehatan yang dihadapi oleh negara-negara Asia Tenggara, termasuk Indonesia adalah rendahnya kandungan nutrisi status anak-anak. Malnutrisi pada anak-anak mempengaruhi sistem kekebalan tubuh terhadap penyakit dan kecerdasan, yang jelas mempengaruhi kualitas sumber daya manusia (6).

Di Indonesia status gizi masih menjadi permasalahan. Menurut Riset Kesehatan Dasar tahun 2013 menjelaskan kasus gangguan gizi pada anak 6-11 tahun sebanyak 9,5\% mengalami gizi kurang, gizi buruk $3,9 \%$, anak pendek $11,6 \%$, sangat pendek $16,9 \%$, anak kurus $7,7 \%$, sangat kurus $6,4 \%$ dan gemuk $15,9 \%$ (7).

Menurut Ghayidayasmin (2010) dalam Muchlis, dkk (8) menyatakan bahwa salah satu faktor yang mempengaruhi prestasi belajar adalah tingkat kecerdasan. Kecerdasan sangat berhubungan dengan tingkat pertumbuhan dan perkembangan selsel otak, dan makanan berpengaruh terhadap perkembangan sel otak. Apabila makanan tidak mengandung kecukupan zatzat gizi yang dibutuhkan dan keadaan ini berlangsung lama maka akan menyebabkan perubahan metabolisme otak dan 
ketidakmampuan otak untuk dapat tumbuh dan berkembang secara optimal, otak membutuhkan zat-zat gizi yang cukup dan seimbang.

Oleh karena itu perlu dilakukan penelitian mengenai "Analisis Status Gizi dengan Prestasi Belajar pada Siswa di SDN Mawar 8 Kota Banjarmasin".

\section{Metode Penelitian}

Penelitian ini merupakan penelitian survey analitik dengan pendekatan Cross Sectional, dimana variabel independen yaitu status gizi sedangkan variabel dependen yaitu prestasi belajar diteliti sekaligus pada saat yang sama/point time aproach. Penelitian ini dilakukan di SDN Mawar 8 Kota Banjarmasin. Populasi dalam penelitian ini adalah seluruh siswa kelas 1 sampai kelas 4 di SDN Mawar 8 Kota Banjarmasin tahun 2018 berjumlah 83 siswa. Besar sampel didapatkan sebanyak 69 responden dengan teknik cluster sampling. Data status gizi didapatkan menggunakan Indeks Massa Tubuh (IMT) menurut umur (IMT/U) yaitu anak umur 5-18 tahun dengan cara melakukan pengukuran tinggi badan menggunakan microtoice dan pengukuran berat badan menggunakan alat timbangan digital serta mencatat data jenis kelamin dan data umur dalam tahun dan bulan penuh. Data prestasi belajar didapatkan berdasarkan nilai raport terakhir.

Pengolahan dan analisa data dilakukan dengan menggunakan alat bantu program komputer. Analisis univariat dilakukan untuk menjelaskan atau mendiskripsikan variabel status gizi (variabel independen) dan prestasi belajar (variabel dependen). Analisis bivariat dilakukan terhadap dua variabel yaitu variabel status gizi (variabel independen) dan prestasi belajar (variabel dependen) pada siswa di SDN Mawar 8 kota Banjarmasin. Uji statistik yang digunakan adalah Chi Square dengan tingkat kepercayaan 95\%.

\section{Hasil Penelitian}

a. Univariat

Tabel 1. Distribusi Frekuensi Berdasarkan Prestasi Belajar dan Status Gizi

\begin{tabular}{clcc}
\hline No & Variabel & n & $\%$ \\
\hline 1. & Prestasi Belajar & & \\
& Kurang Baik & 20 & 29 \\
& Cukup Baik & 34 & 49,3 \\
& Baik & 15 & 21,7 \\
\hline & Jumlah & 69 & 100 \\
\hline 2. & Status Gizi & & \\
& Tidak Normal & 21 & 30,4 \\
& Normal & 48 & 69,6 \\
\hline & Jumlah & 69 & 100 \\
\hline
\end{tabular}

Berdasarkan hasil penelitian di SDN Mawar 8 Kota Banjarmasin Tahun 2018 menunjukkan bahwa proporsi responden sebagian besar mempunyai prestasi belajar yang cukup baik sebesar 49,3\%. Berdasarkan hasil penelitian di SDN Mawar 8 Kota Banjarmasin Tahun 2018 menunjukkan bahwa proporsi responden sebagian besar mempunyai status gizi normal sebesar $69,6 \%$.

\section{b. Bivariat}

Tabel 2. Analisis Status Gizi dengan Prestasi Belajar di SDN Mawar 8 Kota Banjarmasin

\begin{tabular}{|c|c|c|c|c|c|c|c|c|c|}
\hline \multirow{3}{*}{ Variabel } & \multicolumn{6}{|c|}{ Prestasi Belajar } & & & \multirow{3}{*}{ p-value } \\
\hline & \multicolumn{2}{|c|}{$\begin{array}{c}\text { Kurang } \\
\text { Baik }\end{array}$} & \multicolumn{2}{|c|}{$\begin{array}{l}\text { Cukup } \\
\text { Baik }\end{array}$} & \multicolumn{2}{|c|}{ Baik } & \multicolumn{2}{|c|}{ Jumlah } & \\
\hline & $\mathrm{n}$ & $\%$ & $\mathrm{n}$ & $\%$ & $\mathrm{~N}$ & $\%$ & $\mathrm{n}$ & $\%$ & \\
\hline \multicolumn{10}{|l|}{ Status Gizi } \\
\hline Tidak Normal & 11 & 52,4 & 8 & 38,1 & 2 & 9,5 & 21 & 100 & 0,014 \\
\hline Normal & 9 & 18,8 & 26 & 54,2 & 13 & 27,1 & 48 & 100 & \\
\hline
\end{tabular}

\section{Pembahasan}

Distribusi Frekuensi Prestasi Belajar dan Status Gizi pada Siswa SDN Mawar 8 Kota Banjarmasin.

Berdasarkan hasil penelitian di SDN Mawar 8 Kota Banjarmasin Tahun 2018 menunjukkan bahwa prestasi belajar kurang baik sebanyak 20 (29\%), cukup baik sebanyak $34(49,3 \%)$ sedangkan baik sebanyak $15(21,7 \%)$ yang artinya sebagian besar responden mempunyai prestasi belajar yang cukup baik, sedangkan status gizi tidak normal sebanyak $21 \quad(30,4 \%)$ sedangkan status gizi normal sebanyak 48 
$(69,6 \%)$ yang artinya sebagian besar responden mempunyai status gizi normal.

Status gizi adalah keadaan kesehatan individu atau kelompok yang ditentukan oleh derajat kebutuhan fisik akan energi dan zatzat lain yang diperoleh dari makanan yang dampak fisiknya diukur antropometri. Gizi yang cukup diperlukan setiap orang untuk mencapai pertumbuhan yang optimal (9).

Status gizi optimal terjadi bila tubuh memperoleh cukup zat-zat gizi yang digunakan secara efisien. Pengukuran antropometri terbaik adalah menggunakan indikator BB/TB. Ukuran ini dapat menggambarkan status gizi saat ini dengan lebih sensitif dan spesifik. Artinya mereka yang BB/TB (10).

Pada anak usia sekolah kekurangan gizi akan mengakibatkan anak menjadi lemah, cepat lelah dan sakit-sakitan sehingga anak seringkali absen serta mengalami kesulitan mengikuti dan memahami pelajaran. Keadaan gizi juga akan mempengaruhi kemampuan anak dalam mengikuti pelajaran di sekolah dan akan mempengaruhi prestasi belajar, karena salah satu cara menilai kualitas seorang anak adalah dengan melihat prestasi belajarnya di sekolah. Proses belajar yang dilakukan seseorang merupakan suatu proses yang sangat komplek dipengaruhi oleh banyak faktor baik dari diri sendiri maupun dari luar diri manusia tersebut (3).

\section{Status Gizi dengan Prestasi Belajar SDN Mawar 8 Kota Banjarmasin.}

Berdasarkan hasil penelitian di SDN Mawar 8 Kota Banjarmasin Tahun 2018 menunjukkan bahwa proporsi responden yang mempunyai status gizi tidak normal dan mempunyai prestasi belajar yang kurang baik sebesar $52,4 \%$ sedangkan proporsi responden yang mempunyai status gizi normal dan mempunyai prestasi belajar baik sebesar $27,1 \%$. Berdasarkan uji statistik hubungan antara status gizi dengan prestasi belajar diperoleh $p$-value $=0,014$ dengan demikian $p$-value lebih kecil dari nilai $\alpha$ $(0,05)$, hal ini berarti secara statistik ada hubungan bermakna antara status gizi dengan prestasi belajar siswa di SDN Mawar 8 Kota Banjarmasin.

Sejalan dengan penelitian Nurmawati, dkk (3) menyatakan bahwa terdapat hubungan antara status gizi terhadap prestasi belajar siswa kelas IV SD Negeri 1 Pandrah Kabupaten Bireuen dengan proporsi responden yang mempunyai prestasi belajar baik dan status gizi normal sebesar $11,1 \%$ sedangkan proporsi responden yang mempunyai prestasi belajar cukup baik dan status gizi normal sebesar $88,9 \%$.

Sejalan dengan penelitian yang dilakukan oleh Wahyuningsih (5) menunjukkan bahwa sebagian besar responden memiliki status gizi baik sebanyak 17 responden $(56,7 \%)$ dan cenderung memiliki prestasi belajar baik sebanyak 12 responden (40\%). Hasil analisis bivariat diketahui bahwa nilai $p=$ 0,037 berarti $p<0,05$ sehingga ada hubungan antara status gizi dengan prestasi belajar anak SD kelas $\mathrm{V}$ di SDN 1 Kadilanggon Wedi Klaten. Nilai keeratan hubungan dalam penelitian ini sebesar 0,367 yang nilainya termasuk kategori sedang.

Hasil penelitian ini sejalan dengan penelitian Herlina (11) yang menjelaskan Ada hubungan yang signifikan antara Hubungan Status Gizi dengan prestasi Siswa Sekolah Dasar Negeri 081234 Kota Sibolga Tahun 2014 dimana $p<0,05$ ( $p=$ 0,000).

Fase usia sekolah membutuhkan asupan makanan yang bergizi untuk menunjang masa pertumbuhan dan perkembangannya. Selain untuk kebutuhan energi, asupan makanan yang bergizi juga mempengaruhi perkembangan otak, apabila makanan tidak cukup mengandung zat-zat gizi yang dibutuhkan, dan keadaan ini berlangsung lama, akan menyebabkan perubahan metabolisme otak (12).

Anak yang kurang gizi mudah mengantuk dan kurang bergairah yang dapat mengganggu proses belajar di sekolah dan menurun prestasi belajarnya, daya pikir anak juga berkurang karena pertumbuhan otak tidak optimal (13).

Keadaan status gizi dan indeks prestasi merupakan gambaran apa yang dikonsumsi anak sekolah dasar dalam jangka waktu yang lama, dapat berupa gizi kurang maupun gizi lebih. Zat-zat gizi seperti karbohidrat, protein, maupun zat gizi lainnya khususnya zat besi, dalam metabolisme tubuh berperan dalam proses berpikir atau proses penalaran serta daya konsentrasi 
dan sangat berkaitan erat dengan efisiensi belajar (4).

Asupan gizi yang baik berperan penting dalam mencapai pertumbuhan badan yang optimal. Pertumbuhan badan yang optimal ini mencakup pertumbuhan otak yang sangat menentukan kecerdasan seseorang. Dampak akhir dari konsumsi gizi yang baik dan seimbang adalah meningkatnya kualitas sumber daya manusia (4).

Kekurangan gizi pada masa lalu akan menyebabkan perubahan metabolisme dalam otak terutama jika ini terjadi saat golden periode (3 tahun) pertumbuhan dan perkembangan otak anak. Hal ini akan mengakibatkan terjadinya ketidakmampuan otak untuk berfungsi normal. Pada keadaan yang lebih berat dan kronis, kekurangan gizi menyebabkan pertumbuhan terganggu (stunting), badan lebih kecil, jumlah sel dalam otak berkurang dan terjadi ketidakmatangan serta ketidak sempurnaan organisasi biokimia dalam otak. Keadaan ini akan berpengaruh terhadap perkembangan kecerdasan anak.

Menurut Ali (2008) menyatakan bahwa masalah kurang konsumsi gizi harus diatasi sejak dini, kalau menginginkan anak-anak Indonesia tumbuh dan berkembang dengan baik. Dalam jangka panjang kurang gizi akan mengakibatkan hambatan pertumbuhan dan akhirnya berdampak buruk bagi perkembangan mental intelektual individu. Kurang gizi pada fase cepat tumbuh otak akan bersifat ireversibel yang artinya kecerdasan anak tersebut tidak bisa lagi berkembang secara optimal. Ini jelas akan semakin menurunkan kualitas bangsa Indonesia. Kekurangan Energi Protein (KEP) pada masa anak akan menurunkan IQ, meyebabkan kemampuan geometrik rendah, dan anak tidak bisa berkonsentrasi secara maksimal (14).

Menurut Devi (2012) menyatakan bahwa perilaku gizi yang salah pada anak sekolah perlu mendapat perhatian. Misalnya, tidak sarapan pagi, jajanan yang tidak sehat di sekolah, kurang mengonsumsi sayuran dan buah, terlalu banyak mengonsumsi fast food dan junk food, terlalu banyak mengonsumsi zat makanan tambahan seperti pengawet, pewarna, dan penambah rasa (15).
Menurut Ghayidayasmin

(2010) menyatakan bahwa salah satu faktor yang mempengaruhi prestasi belajar adalah tingkat kecerdasan. Kecerdasan sangat berhubungan dengan tingkat pertumbuhan dan perkembangan sel-sel otak, dan makanan berpengaruh terhadap perkembangan sel otak. Apabila makanan tidak mengandung kecukupan zat-zat gizi yang dibutuhkan, dan keadaan ini berlangsung lama maka akan menyebabkan perubahan metabolisme otak dan ketidakmampuan otak untuk dapat tumbuh dan berkembang secara optimal, otak membutuhkan zat-zat gizi yang cukup dan seimbang (16).

Prestasi belajar siswa bukan sematamata karena kecerdasan siswa saja tetapi ada faktor lain yang dapat mempengaruhi prestasi belajar tersebut. Faktor-faktor yang mempengaruhi prestasi belajar siswa adalah faktor internal yang meliputi faktor fisiologis dan psikologis, dimana status gizi termasuk faktor fisiologis tersebut, faktor eksternal, dan faktor pendekatan belajar (17).

Bukti penelitian yang kuat menjelaskan bahwa praktek pemberian makan yang buruk berhubungan dengan gangguan pertumbuhan dan menyebabkan penundaan perkembangan mental sehingga keduanya menyebabkan kinerja sekolah yang buruk dan kecerdasan intelektual kurang (6).

\section{Kesimpulan dan Saran}

Berdasarkan hasil penelitian di SDN Mawar 8 Kota Banjarmasin Tahun 2018 menunjukkan bahwa 1 diantara 4 responden mempunyai prestasi belajar yang baik, sedangkan 1 diantara 3 responden mempunyai status gizi yang tidak normal. Secara statistik terdapat hubungan yang bermakna antara status gizi dengan prestasi belajar di SDN Mawar 8 Kota Banjarmasin dengan $p$-value $(0,014)<\alpha(0,05)$. Hal ini membuktikan bahwa faktor status gizi mempunyai kontribusi besar terhadap prestasi belajar pada siswa. Disarankan perlunya adanya kerjasama dari pihak sekolah dengan orang tua siswa dalam hal penyediaan sarapan pagi dan sarapan siang yang sehat dan bergizi setiap hari, selain itu juga, melakukan kajian penelitian lebih lanjut mengenai penyebab yang paling mendasar menggunakan pendekatan case control dan uji multivariate untuk mengetahui faktor 
penyebab yang dominan terhadap prestasi belajar pada siswa.

\section{Daftar Pustaka}

1. Amany, Tazkya dan Sekartini, Rini., 2017. Sari Pediatri. Hubungan Antara Status Gizi dengan Prestasi Belajar Siswa SDN 03 Pondok Cina Depok Tahun 2015. Vol. 18, No. 6 April 2017. [Online].https://saripediatri.org/index.php /sari-pediatri/article/view/381. [Accessed 19 September 2018].

2. Ariyasa, I Gede dan Datya, Aulia Lefan., 2016. VIRGIN : Jurnal IImiah Kesehatan dan Sains. Pengaruh Sarapan Pagi dan Status Gizi Terhadap Prestasi Belajar Siswa Sekolah Dasar di Kabupaten Buleleng. Jilid II, No. I Januari 2016. [Online].https://jurnal.undhirabali.ac.id/in dex.php/virgin/article/view/105/96.

[Accessed 19 September 2018].

3. Nurmawati., Maryam, Siti., Muamar, M. Rezeki., 2014. Jurnal Edukasi dan Sains Biologi (JESBIO). Hubungan Status Gizi Terhadap Prestasi Belajar Siswa Kelas IV SD Negeri 1 Pandrah Kecamatan Pandrah Kabupaten Bireuen. Vol.3,No.1.[Online].http://id.portalgaruda .org/?ref=browse \&mod=viewarticle\&artic $\mathrm{le}=429911$. [Accessed 19 September 2018].

4. Sa'adah, Rosita Hayatus., Herman, Rahmatina B., dan Sastri, Susila., 2014. Jurnal Kesehatan Andalas. Hubungan Status Gizi dengan Prestasi Belajar Siswa Sekolah Dasar Negeri 01 Guguk Malintang Kota Padangpanjang. Vol. 3, No.3.[Online].http://jurnal.fk.unand.ac.id/ index.php/jka/article/view/176.

[Accessed 19 September 2018].

5. Wahyuningsih, Endang., 2014. Jurnal Involusi Kebidanan. Hubungan Status dengan Prestasi Belajar pada Anak Kelas V SDN 01 Kadilanggon Wedi Klaten. Vol. 4, No. 8 Juni. [Online]. http://ejournal.stikesmukla.ac.id/index.ph p/involusi/article/view/245. [Accessed 19 September 2018].

6. Kunang, Analia., 2017. Jurnal IImiah Kesehatan. Korelasi Status Gizi dengan Prestasi Belajar pada Siswa Sekolah Dasar. Vol. 6, No. 1 Januari 2017.[Online]. http://e-journal.stikesmuhpringsewu.ac.id/index.php/JIK/article/vie w/88. [Accessed .[Accessed 19 September 2018].

7. Badan Penelitian dan Pengembangan Kesehatan Departemen Kesehatan (Balitbangkes) RI, 2013. Laporan Hasil Riset Kesehatan Dasar. [Online] .http://www.litbang.depkes.go.id.[Access ed 19 September 2018].

8. Muchlis., Ernalia, Yanti., Firdaus., 2015. Jurnal Online Mahasiswa (Jom) FK Universitas Riau. Hubungan Status Gizi dengan Prestasi Belajar Siswa Sekolah Dasar Negeri 063 di Pesisir Sungai Siak Kecamatan Rumbai Pesisir Kota Pekanbaru. Vol. 3, No. 1 Oktober 2015. [Online].https://jom.unri.ac.id/index.php/ JOMFDOK/article/view/8224. [Accessed 19 September 2018].

9. Suharjo, 2003. Berbagai cara pendidikan gizi. Jakarta : Bumi Aksara.

10. Almatsier, Sunita., 2003. Prinsip Dasar IImu Gizi. Jakarta : Gramedia Pustaka Utama.

11. Herlina, 2015. Hubungan Status Gizi Dengan Prestasi Siswa Sekolah Dasar Negeri 081234 Kota Sibolga Tahun 2014. Wahana Inovasi. Vol 4. No.1. Hal 64-71

12. Cakrawati D., 2012. Bahan pangan, gizi, dan kesehatan. Bandung : Alfabeta.

13. Gibney M., 2009. Gizi kesehatan masyarakat. Jakarta : EGC.

14. Ali, AR., 2008. Perbedaan Kadar Hb, Status Gizi dan Prestasi Belajar Anak SD Wilayah Pantai dan Pegunungan di Kab. Polewali Mandar Tahun Ajaran 2005/2006. Hal 1-3.

15. Devi N.,2012. Kebutuhan Gizi Anak Sekolah. In: Gizi Anak Sekolah. Jakarta: Kompas. p. 47.

16. Ghayidayasmin, 2010. Gizi dan kecerdasan.[Online].http://www.ghayida yasmin.wordpress.com.[Accessed 23 Februari 2019].

17. Agustini, Creisye Cynthia., Malonda, Nancy S.H., Purba, Rudolf B., 2013. Hubungan Antara Status Gizi dengan Prestasi Belajar Anak Kelas 4 dan 5 Sekolah Dasar di Kelurahan Maasing Kecamatan Tuminting Kota Manado. [Online].https://fkm.unsrat.ac.id/wpconte nt/uploads/2013/08/creisye cynthiaagustini.pdf. [Accessed 23 Februari 2019]. 